\title{
Fullerene-silicon polymerization evidence
}

\author{
Di Liscia EJ ${ }^{1,2 *}$, Huck-Iriart $C^{2,3}$, Halac EB ${ }^{1,2}$, Reinoso $\mathrm{M}^{1,2,3}$ and Huck $\mathrm{H}^{1,2}$ \\ ${ }^{1}$ Gerencia de Física, GIyA, Comisión Nacional de Energía Atómica, Avda. General Paz 1499, (1650) Gral. San Martín, Pcia. Buenos Aires, Argentina \\ ${ }^{2}$ Escuela de Ciencia y Tecnología, Universidad Nacional de San Martín, Martín de Irigoyen 3100 (1650) Gral. San Martín, Pcia. Buenos Aires, Argentina \\ ${ }^{3}$ CONICET, Rivadavia 1917, (1033) Buenos Aires, Argentina
}

\begin{abstract}
We report experimental results for $\mathrm{C}_{60}-\mathrm{Si}$ deposition by simultaneous thermal vaporization of fullerene source and chemical vapor deposition from silane source. The samples were characterized by Scanning Electron Microscopy, Energy-dispersive X-ray spectroscopy, Micro-Raman spectroscopy, Wide-angle X-ray scattering, X-ray photoelectron spectroscopy and its thermal stability was studied, discussed and compared with pure $\mathrm{C}_{60}$ deposited by the same method. A crystalline material was obtained and results suggest that a polymerization of fullerenes bridged by silicon atoms was achieved.
\end{abstract}

\section{Introduction}

Many works have been published about fullerenes and in particular about $\mathrm{C}_{60}$ or buckyminsterfullerene, the most stable of fullerenes. Its properties are of great value in a diversity of applications like organic solar cells, hydrogen gas storage, metals strengthening/hardening, optical limiters, solid sensors, drug carriers, etc [1-8]. The fabrication of novel nanostructured materials from fullerenes is promising for several of these applications. However weak van der Waals bond between fullerenes is a serious limitation for some applications and polymerization has been a vastly studied solution. A variety of fullerene polymers were reported, using photopolymerization, pressure-induced polymerization, charge-transfer polymerization mediated by metals, electron beam-induced and plasma-induced polymerization as some strategies to prepare the so-called all-carbon polyfullerenes [9-15]. In particular, using Group IV elements in order to bind fullerene molecules has been investigated and both theoretical and experimental works about fullerenes molecules bonded by silicon bridges have been published by Masenelli et al. and Fujiwara et al. [16-19], which motivates the possibility to construct a polymerized fullerene-silicon material.

We report experimental results for deposition of $\mathrm{C}_{60}$-Si material by simultaneous thermal vaporization of fullerene source and chemical vapor deposition from silane source. The materials produced were characterized by Scanning Electron Microscopy, (SEM), Energydispersive X-ray spectroscopy (EDS), Micro-Raman spectroscopy, Wide-angle X-ray scattering (WAXS), X-ray photoelectron spectroscopy (XPS) and their thermal stability was also studied.

\section{Experimental}

Fullerene and Si were deposited on $\mathrm{Ge}(100)$ and $\mathrm{Si}(100)$ wafers in a vacuum chamber. Fullerene source was pristine $\mathrm{C}_{60}$ powder $\left(99.9 \% \mathrm{C}_{60}\right)$ evaporated at $550^{\circ} \mathrm{C}$ and silane $\left(\mathrm{SiH}_{4}\right)$ was introduced in the chamber and dissociated on a tungsten hot filament in order to incorporate silicon atoms to the $\mathrm{C}_{60}$ lattice. Fullerene source was degassed in situ at $300^{\circ} \mathrm{C}$ and $5.10^{-7} \mathrm{mbar}$ for several hours in order to release the oxygen that could be trapped in it. The deposition process was carried at $5.10^{-5}$ mbar with both evaporated fullerene and dissociated silane mixing in the chamber. The substrate was polarized at $-30 \mathrm{~V}$ during the process. Substrates were cleaned by an acetone ultrasonic bath. For the sake of comparison, pure fullerene and pure silicon were separately deposited in the same conditions and by the methods used for the mixed samples. Also, in some samples pure fullerene and $\mathrm{C}_{60}-\mathrm{Si}$ were simultaneously deposited in different zones of the substrate, in order to compare the thermal stability of each material under the same conditions.

Both pure fullerene and fullerene-silicon samples were analyzed by Scanning electron microscopy (SEM), Energy-dispersive X-ray spectroscopy (EDS), Micro-Raman spectroscopy, Wide-angle X-ray scattering (WAXS) and X-ray photoelectron spectroscopy (XPS). Microscopy was carried on by a SEM Carl Zeiss NTS SUPRA 40. Raman spectra were recorded using a LabRAM HR Raman system (Horiba Jobin Yvon), equipped with a confocal microscope and a charge coupled device detector (CCD). A 100X objective lens was used, generating a $1.5 \mu \mathrm{m}$ spot. An $1800 \mathrm{~g} / \mathrm{mm}$ grating and $100 \mu \mathrm{m}$ hole results in a $2 \mathrm{~cm}^{-1}$ spectral resolution. The $514 \mathrm{~nm}$ line of an $\mathrm{Ar}^{+}$ laser was used as excitation source. The laser power density over the sample was between $0.4 \mathrm{~W} \cdot \mathrm{mm}^{-2}$ and $4 \mathrm{~W} \cdot \mathrm{mm}^{-2}$. WAXS experiments were performed at INIFTA facilities using a XEUSS 1.0 equipment from XENOCS with a $\mathrm{K}_{\alpha}-\mathrm{Cu}$ radiation micro-source. A PILATUS$100 \mathrm{~K}$ detector was used with $13 \mathrm{~cm}$ sample detector distance. Onedimensional curves were obtained by integration of the $2 \mathrm{D}$ data using the Foxtrot program. The scattering intensity distributions as a function of the scattering angle $(2 \theta)$ were obtained in the $2 \theta$ range between $3^{\circ}$ and $39^{\circ}$. The samples were placed in a motorized sample holder suitable for grazing incidence measurements at room temperature. XPS experiments were made using a Multitécnica Specs equipped with a dual $\mathrm{Ag} / \mathrm{Al}$ monochromatic X-ray source and a PHOIBOS 150 hemispheric analyzer in fixed analyzer transmission mode (FAT). The spectra were obtained with $30 \mathrm{eV}$ energy and an $\mathrm{Al}$ monochromatic

Correspondence to: Di Liscia EJ, Gerencia de Física, GlyA, Comisión Nacional de Energía Atómica, Avda. General Paz 1499, (1650) Gral. San Martín, Pcia. Buenos Aires, Argentina, E-mail: diliscia@tandar.cnea.gov.ar

Received: October 28, 2017; Accepted: December 05, 2017; Published: December 09, 2017 
anode at $300 \mathrm{~W}$. The measurements were made on a $2 \mathrm{~mm}^{2}$ area over the sample and at different depths, removing material by sputtering. For the data analysis, the spectra were fitted by Gaussian/Lorentzian convolution functions with a previous optimization of the background parameters. The background was modeled by a Shirley background function.

Some deposited samples were annealed in vacuum $\left(5.10^{-7} \mathrm{mbar}\right)$ at $600^{\circ} \mathrm{C}$ after deposition in order to study the material thermal stability.

\section{Results}

SEM images for pure fullerene and $\mathrm{C}_{60}-\mathrm{Si}$ samples are shown in Figure 1. In the later, hexagonal structures of a few $\mu \mathrm{m}$ are clearly observed, a major morphologic difference with pure $\mathrm{C}_{60}$ samples. EDS measurements over several points at different crystals on $\mathrm{C}_{60}-\mathrm{Si}$ samples grown on $\mathrm{Ge}(100)$ substrates, mainly detected both $\mathrm{C}$ and $\mathrm{Si}$ presence at an atomic ratio less than $2 \% \mathrm{Si}$ respect to $\mathrm{C}$. Also, a weak signal of oxygen was measured, which could have been absorbed after deposition when exposed to air. Germanium corresponding to the substrate was also observed.

Raman spectra from pristine, deposited fullerene and from $\mathrm{C}_{60}{ }^{-}$ $\mathrm{Si}$ samples are shown in Figure 2. If a power density above $4 \mathrm{~W} /$ $\mathrm{mm}^{2}$ is used a clear change in the spectra is observed. The spectra show no significant differences between the samples. The breathing frequencies of pristine fullerene were observed in both deposited $\mathrm{C}_{60}$ and $\mathrm{C}_{60}-\mathrm{Si}$ samples, indicating that fullerenes were not broken during deposition. Si-Si signal was not observed, suggesting that there was not $\mathrm{Si}$ segregation. The spectra for pure silicon samples show the characteristic bands of amorphous silicon [20].

WAXS results are shown in Figure 3. Peaks corresponding to cubic and hexagonal (marked by arrows) fullerene structures are observed in both deposited $\mathrm{C}_{60}$ and $\mathrm{C}_{60}$-Si samples [21]. Broader peaks than in the case of pristine fullerene (our source material) could indicate smaller grain sizes. Peak positions for the cubic symmetry are the same for all samples and this implies that silicon atoms among fullerenes are not significantly changing the lattice parameters nor the distance between fullerenes. WAXS pattern's peaks after $600^{\circ} \mathrm{C}$ in vacuum annealing become a little thinner, but both cubic and hexagonal phases are still present.

As cubic phase was the predominant one, numerical calculations were made using the semiempirical many-body Tersoff potentials, which had been used and achieved a good description of carbon fullerenes, including several polymeric phases [14,22]. A zincblende $\mathrm{C}_{60}-\mathrm{Si}$ structure was found to be stable.

Results for XPS measurements for annealed $\mathrm{C}_{60}-\mathrm{Si}$ samples are shown in Figure 4. The peaks can be assigned to $\mathrm{Si}_{2 \mathrm{p}}, \mathrm{Si}_{2 \mathrm{~s}}, \mathrm{C}_{1 \mathrm{~s}}$ and $\mathrm{O}_{1 \mathrm{~s}}$.
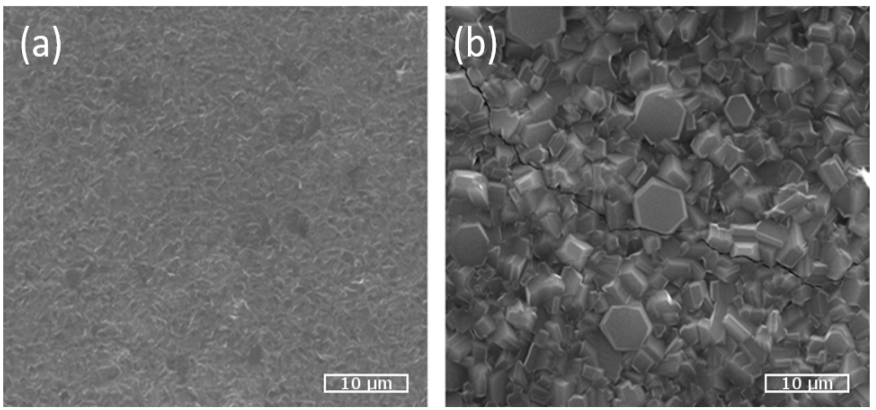

Figure 1. SEM images for pure deposited $\mathrm{C}_{60}$ (a) and deposited $\mathrm{C}_{60}-\mathrm{Si}(\mathrm{b})$.
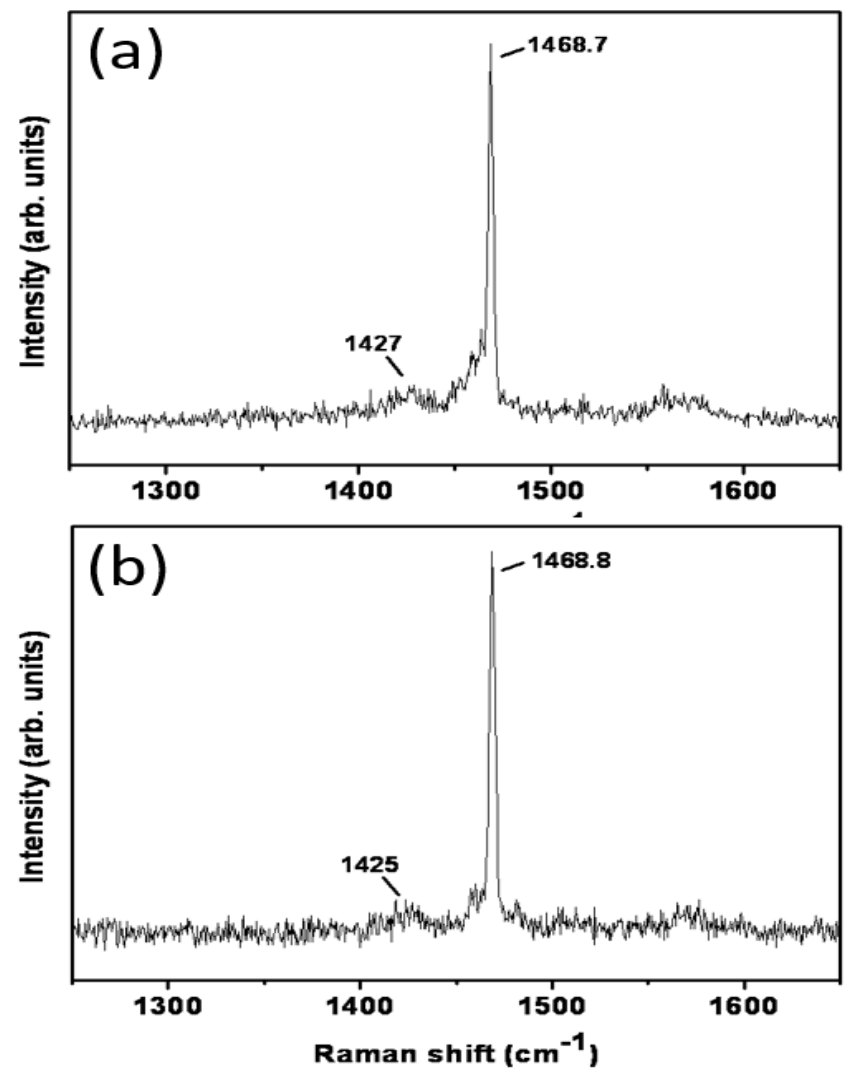

Figure 2. Raman spectra for pure $\mathrm{C}_{60}(\mathrm{a})$ and $\mathrm{C}_{60} \mathrm{Si}(\mathrm{b})$ deposited samples.

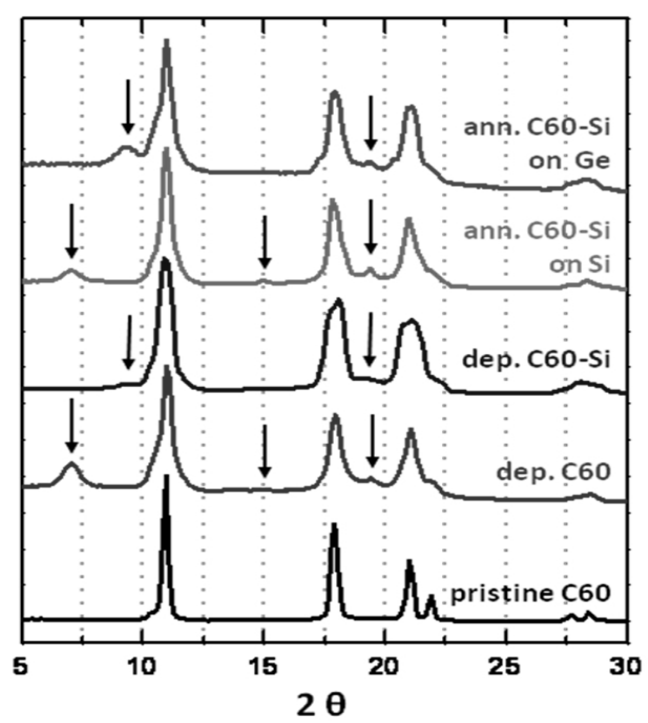

Figure 3. WAXS patterns from pristine $\mathrm{C}_{60}$, deposited $\mathrm{C}_{60}$ and $\mathrm{C}_{60}-\mathrm{Si}$ on $\mathrm{Si}(100)$ wafer and $\mathrm{C}_{60}-\mathrm{Si}$ samples deposited on $\mathrm{Si}(100)$ and $\mathrm{Ge}(100)$ wafers and annealed to $600^{\circ} \mathrm{C}$ after deposition.

The peaks position and width shown in Fig 4. lightly change at different depths. An atom proportion of $53.4 \%$ carbon, $27.2 \%$ silicon and $19.4 \%$ oxygen was found (after 60 seconds of argon sputtering at $1000 \mathrm{~V}$ ), which ensures an enough quantity of silicon in order to conform a zincblende structure as proposed in the simulation results.

In Figure $4(\mathrm{~b})$ and (c) the analysis for $\mathrm{Si}_{2 \mathrm{p}}$ and $\mathrm{O}_{1 \mathrm{~s}}$ XPS signals is shown. The envelop of each $\mathrm{Si}_{2 \mathrm{p}}$ contribution was the result of $2 \mathrm{p} 3 / 2$ 

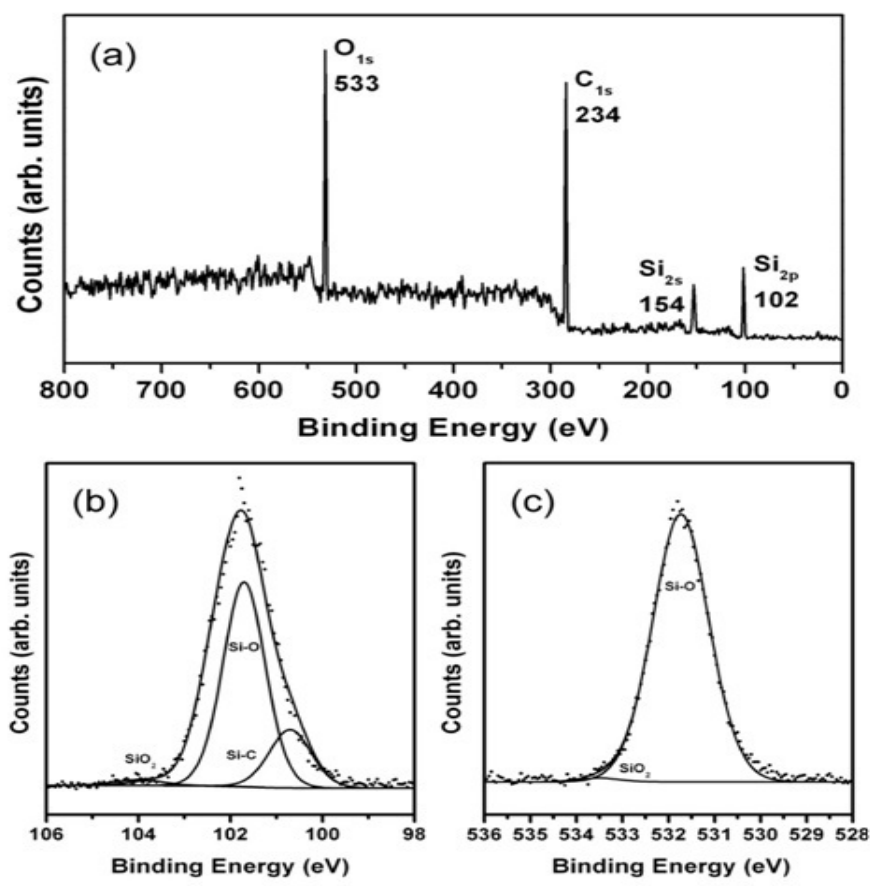

Figure 4. XPS measurement for $\mathrm{C}_{60}$-Si deposited sample. (a) survey and fitting for $\mathrm{Si}_{2 \mathrm{p}}$ (b) and $\mathrm{O}_{1 \mathrm{~s}}(\mathrm{c})$ signals

and 2 p $1 / 2$ orbitals summation where the doublet separations energy and the branching ratio were fixed in $0.6 \mathrm{eV}$ and $0.5 \mathrm{eV}$ respectively. From the $\mathrm{Si}_{2 \mathrm{p}}$ signal analysis, a proportion of $21.7 \% \mathrm{Si}-\mathrm{C}, 1.6 \% \mathrm{SiO}_{2}$ and $76.7 \% \mathrm{Si}-\mathrm{O}$ was calculated. For $\mathrm{O}_{1 \mathrm{~s}}$ signal, mostly $\mathrm{Si}-\mathrm{O}$ was found, which could be attributed to some species like $\mathrm{CSiO}_{n}(\mathrm{n}<3)$ [23], and around $1 \%$ of $\mathrm{SiO}_{2}$. It is hard to fit correctly for $\mathrm{C}_{1 \mathrm{~s}}$ signal, as $\mathrm{C}-\mathrm{C}$ bonds are indistinguishable from $\mathrm{C}$-Si ones. But the peak is consistent with a mixture of signals from $\mathrm{C}-\mathrm{Si}, \mathrm{C}-\mathrm{C}\left(\mathrm{sp}^{3}\right.$ carbons) and $\mathrm{C}=\mathrm{C}$ ( $\mathrm{sp}^{2}$ carbons) bonds. By analyzing $\mathrm{O}_{1 \mathrm{~s}}$ and $\mathrm{C}_{1 \mathrm{~s}}$ results, it can be ensured that a negligible amount of $\mathrm{C}=\mathrm{O}$ and $\mathrm{C}-\mathrm{O}$ bonds are present in the sample [24-28].

The thermal stability is the most outstanding result. While deposited $\mathrm{C}_{60}$ samples are completely wiped out when annealed in vacuum at $600^{\circ} \mathrm{C}$, leaving the substrate totally clean, $\mathrm{C}_{60}-\mathrm{Si}$ samples morphology and Raman spectra are unchanged. Even for the samples where pure fullerene and $\mathrm{C}_{60}-\mathrm{Si}$ were simultaneously deposited in different zones of the substrate, the $\mathrm{C}_{60}$ was completely removed while the mixed material remained unaltered. This result implies that covalent bonds were formed between fullerenes.

\section{Conclusion}

It was observed that crystalline structures are formed when $\mathrm{C}_{60}$ and silicon are simultaneously deposited by the described method. This is clearly suggested by the shapes observed by SEM and confirmed by WAXS. Looking at the diffractograms is possible to affirm that cubic $f c c$ and hexagonal structures are present in the sample, the former in agreement with our simulation results. While both could be assigned to a pure $\mathrm{C}_{60}$ material, the presence of silicon was confirmed by EDS and XPS also no evidence of segregation was found. Moreover, XPS analysis evidenced a considerable proportion (27.1\%) of silicon atoms bonded to carbon atoms, but measuring over individual crystals by EDS a relation lesser than $2 \%$ was found between silicon and carbon atoms. Even more significant, the samples show no perceptible alterations after an annealing at $600^{\circ} \mathrm{C}$, a temperature at which pure $\mathrm{C}_{60}$ samples deposited by the same method were completely cleaned. This suggests that covalent bonds were formed between fullerenes when $\mathrm{C}_{60}$ deposition is carried simultaneously with silicon deposition. Moreover, calculations employing the semiempirical many-body Tersoff potential found a zincblende structure to be stable and such configuration is in concordance with most of our experimental results.

\section{Acknowledgments}

WAXS experiments at INIFTA were performed thanks to project "Nanopymes" (EuropeAid/132184/D/SUP/AR-Contract31-896).

\section{References}

1. Ulloa E (2013) Fullerenes and their Applications in Science and Technology, 4138296 EEE-5425, Introduction to Nanotechnology, Spring.

2. Goodarzi S, Ros TD, Conde J, Sefat, F, Mozafari M (2017). Fullerene: biomedical engineers get to revisit an old friend. Mater Today 20: 460.

3. Klupp G, Margadonna S, Prassides K (2001) Encyclopedia of Materials: Science and Technology 3379.

4. Ganesamoorthy R, Sathiyan G, Sakthivel P (2017) Fullerene based acceptors for efficient bulk heterojunction organic solar cell applications Mat Sol C 161: 102.

5. Coro J, Suárez M, Silva LSR, Eguiluz KIB, Salazar-Banda GR (2016) Fullerene applications in fuel cells: A review. Int J Hydrogen Energ 41: 17944

6. EL-Barbary AA (2016) Hydrogenation mechanism of small fullerene cages. Int $J$ Hydrogen Energ 41: 375 .

7. Gaboardi M, Amadé NS, Aramini M, Milanese C, Magnani G (2017) Carbon 120: 77

8. Dong Y, Saini D, Echegoyen LA, Podila R (2016) Passive optical switches based on endohedral fullerenes. Optical Materials 53: 14.

9. Melinon P, Masenelli B (2012) From Small Fullerenes to Superlattices: Science and Applications. CRC Press.

10. Tanaka H, Osawa S, Onoe J, Takeuchi K (1999) Formation Process of Si-Coated C60. J. Phys. Chem 103: 5939.

11. Tournus F, Masenelli B, Melinon P, Blasé X, Perez A (2002) Bridging $C_{60}$ by silicon: Towards non-Van der Waals $\mathrm{C}_{60}$-based materials. Phys. Rev. B 65: 165417

12. Reinke P, Oelhafen P, Christiansen S (2002) Three-dimensional structures formed with $\mathrm{C} 60$ and amorphous silicon--a feasibility study on the formation of a composite material. Surface Science 507-510: 630-635.

13. Berber S, Osawa E, Tománek D (2014) Rigid crystalline phases of polymerized fullerenes. Phys. Rev. B 70: 085417.

14. Burgos E, Halac E, Weht R, Bonadeo H, Artacho E, et al. (2000) New superhard phase for three-dimensional C60-based fullerites Phys Rev Lett 85: 2328-2331. [Crossref]

15. Giacalone F, Martín N (2006) Fullerene polymers: synthesis and properties. Chem Rev 106: 5136-5190. [Crossref]

16. Masenelli B, Tournus F, Mélinon P, Pérez A, Blasé X (2002) Ab initio study of $\mathrm{C}_{60} \mathrm{C}_{60}-$ silicon clusters $J$. Chem. Phys 117: 10627.

17. Masenelli B, Tournus F, Mélinon P, Blasé X, Perez A (2004) Nanostructured films from $\left(\mathrm{C}_{60}\right)_{\mathrm{n}} \mathrm{Si}_{\mathrm{m}}$ clusters. Appl. Surf. Sci 226: 226.

18. Masenelli B, Tournus F, Melinon P, Blasé X, Perez A (2003) Surf. Sci 532-535: 875

19. Fujiwara K, Komatsu K (2002) Mechanochemical synthesis of a novel C(60) dimer connected by a silicon bridge and a single bond. Org Lett 4: 1039-1041. [Crossref]

20. Avakyants LP, Gerasimov LL, Gorelik VS, Manja NM, Obraztsova ED (1992) Raman scattering in amorphous silicon films. J. Mol. Struct 267: 177-184.

21. Miyazawa K, Minato J, Mashino T, Nakamura S, Fujino M (2006) Structural characterization of room-temperature synthesized fullerene nanowhiskers. Nukleonika 51: 41 .

22. Burgos E, Halac E, Bonadeo H (1998) A semi-empirical potential for the statics and dynamics of covalent carbon systems. Chem Phys. Lett 298: 273

23. David L, Bhandavat R, Barrera U, Singh G (2016) Silicon oxycarbide glass-graphene composite paper electrode for long-cycle lithium-ion batteries. Nat Commun 7: 10998 [Crossref]

24. Watanabe H, Hosoi T () Fundamental Aspects of Silicon Carbide Oxidation. Physics and Technology of Silicon Carbide Devices, Chapter 12. 
25. Wang YY, Kusumoto K, Li CJ (2012) XPS Analysis of SiC Films Prepared by Radio Frequency Plasma Sputtering. Physics Procedia 32: 95.

26. Hueso JL, Espinós JP, Caballero A, Cotrino J, González-Elipe AR (2007) XPS investigation of the reaction of carbon with $\mathrm{NO}, \mathrm{O} 2, \mathrm{~N} 2$ and $\mathrm{H} 2 \mathrm{O}$ plasmas. Carbon 45: 89
27. Sreemany M, Ghosh TB, Pai BC, Chakraborty M (1998) XPS Studies on the Oxidation Behavior of SiC Particles. Mater. Res. Bull 33: 189

28. Kusunoki I, lgari Y (1992) XPS study of a SiC film produced on $\mathrm{Si}$ (100) by reaction with $\mathrm{C}_{2} \mathrm{H}_{2}$ beam. Appl. Surf. Sci 59: 95 .

Copyright: @2017 Di Liscia EJ. This is an open-access article distributed under the terms of the Creative Commons Attribution License, which permits unrestricted use, distribution, and reproduction in any medium, provided the original author and source are credited. 